\title{
Inhalt / Contents
}

Guest Editorial.

204-209

\section{Abhandlungen / Original Papers}

Franck, Egon, Philipp Theiler, One for Sure or Maybe Three. Empirical Evidence for Overtime Play from a Comparison of Swiss Ice Hockey and the NHL. . . . 210-223

Bäker, Agnes, Mario Mechtel, Karin Vetter, Beating thy Neighbor: Derby Effects in German Professional Soccer . . . . . . . . . . . . . . . . . . . 224-246

Nüesch, Stephan, Hartmut Haas, Empirical Evidence on the „Never Change a Winning Team" Heuristic. . . . . . . . . . . . . . . . . . . . 247-257

Süssmuth, Bernd, Stefan Wagner, A Market's Reward Scheme, Media Attention, and the Transitory Success of Managerial Change. . . . . . . . . 258-278

Leeds, Eva Marikova, Michael A. Leeds, Gold, Silver, and Bronze: Determining National Success in Men's and Women's Summer Olympic Events . . . . . . . . 279-292

Kamst, Richard, Gerard H. Kuper, Gerard Sierksma, Bertus G. Talsma, InnerOuter Lane Advantage in Olympic 1000 Meter Speed Skating . . . . . . . . . 293-307

Baumann, Robert, Bryan Engelhardt, Victor A. Matheson, Employment Effects of the 2002 Winter Olympics in Salt Lake City, Utah . . . . . . . . . . . . 308-317

Haan, Marco A., Ruud H. Koning, Arjen van Witteloostuijn, The Effects of Institutional Change in European Soccer . . . . . . . . . . . . . . . .

Dietl, Helmut, Tobias Duschl, Egon Franck, Markus Lang, A Contest Model of a Professional Sports League with Two-Sided Markets . . . . . . . . . . . . 336-359

Frick, Bernd, Björn Wallbrecht, Infant Mortality of Professional Sports Clubs: An Organizational Ecology Perspective . . . . . . . . . . . . . . . . 360-389

\section{Buchbesprechung / Book Review}

Gilli, Manfred, Dietmar Maringer, Enrico Schumann, Numerical Methods and

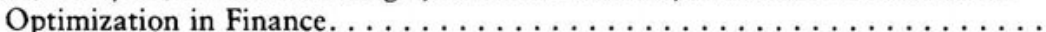

